\title{
Factors Influencing Waste Generation in Buildings Project in South- West, Nigeria
}

\author{
Tongo $\mathrm{SO}^{1,2 *}$, Oluwatayo $\mathrm{AA}^{2}$, Adeboye $\mathrm{BA}^{1}$ \\ ${ }^{1}$ Department of Architecture, Faculty of Environmental Studies, Olabisi Onabanjo University, Ago-Iwoye, Ogun State, Nigeria; ${ }^{2}$ Department \\ of Architecture, College of Science and Technology, Covenant University, Ota, Ogun State, Nigeria
}

\begin{abstract}
The study was aimed to assess the factors influencing waste generation in buildings project in southwestern, Nigeria. The study randomly sampled 261 professionals through a questionnaire survey. Tables and figures were used to present the collected data and ranking and percentage were used to analyze the data collected. It was revealed that Design (Frequent design changes and poor design) lack of early contractor involvement, last-minute client requirement, engagement of inexperience designer, undefined project brief, poor design quality are the most important factors that influence 1 waste generation during buildings project. It was recommended that site operatives and craft men should be equipped with waste minimization knowledge, they should carry along in every management decision regarding waste management plan development as a major player on sites.
\end{abstract}

Keywords: Factors; Building-waste; Waste-generation; Buildings; Building-project; South-West

\section{INTRODUCTION}

Waste is generated in all the building project phases [1]. The waste generated contribute to environmental problems [2]. Several studies defined waste generated in building construction as construction rubbles, ruins, disaster, construction materials and building construction and demolition, site clearance and other forms of waste during the building construction process $[3,4]$. The waste generated has instigated serious problems both locally and globally.

This is generated due to such factors as construction preparation, site preparation, material damage, material use, over-purchased, and human error [5]. For examples, construction materials such as packaging materials, area cleaning and excavation materials, metal, plaster, concrete, brick, insulation, wood, plastic, glass, asphalt, composite materials, and onsite cleaning. Due to nature, certain types of wastes are not found. Liquid waste such as asbestos and lead, paint and kerosene, hazardous materials such as food waste, tires and residue containers are some of the materials. The buildings are located at the heart of all our needs for water, energy, and materials, but at the same time, there is a waste.

Horvath [6] emphasized that the construction industry is one of the largest and most important industries, being at the same time the main consumer of natural resources and one of the largest polluters and employers of labour. This contributes significantly to the overall cost of the construction project; therefore, material wastage has an adverse impact on construction cost, contractor's profit margin, construction duration and can be a possible source of dispute among parties to a project.

The cost of material waste generated on building sites denotes avoidable cost in construction which is eliminated or reduced. The degree to which waste can be prevented in the construction industry has been a long-debated issue. The cost reduction achieved by preventing the generation of construction waste is equally of direct benefit to all stakeholders on a construction project [6]. There are very few local studies similar to the factors influencing a generation of construction waste in Nigeria [4-11]. They all emphasized those unnecessary materials wastage in the Nigerian construction industry was due to improper management.

Adewuyi, et al. [6] assesses the level of contribution of several factors to construction material waste generation and found that first three highest contributors to material waste are found to be reworks due to non-conformance to specifications, waste from cutting uneconomical shapes, and design changes and revisions with average relative contribution index of $0.801,0.791$ and 0.773 respectively. Popoola, et al. [11] appraised material wastage on selected Building Construction sites in Osun State using percentage frequency table and relative importance index and found that

${ }^{*}$ Correspondence to: Samuel Tongo, Department of Architecture, Faculty of Environmental Studies, Olabisi Onabanjo University, Ago-Iwoye, Ogun State, Nigeria, Tel: 08053430957; E-mail: stongo2@yahoo.com

Received: December 30, 2019; Accepted: January 22, 2020; Published: January 30, 2020

Citation: Tongo SO, Oluwatayo AA, Adeboye BA (2020) Factors Influencing Waste Generation in Buildings Project in South-West, Nigeria. Int J Waste Resour 9:371. doi: 10.35248/2252-5211.19.10.371

Copyright: (C) 2020 Tongo SO, et al. This is an open-access article distributed under the terms of the Creative Commons Attribution License, which permits unrestricted use, distribution, and reproduction in any medium, provided the original author and source are credited. 
identified factors that contribute to wastage on-site as operational attribute (poor workmanship), design and documentation attribute (lack of detailed information in the drawing), Site management and practices (Change of Instruction on-site) and Environmental attributes (Poor access road and severe weather condition).

Furthermore, Eze, et al. [5] assessment of materials waste in the construction industry: a view of construction operatives, tradesmen and artisans in Nigeria. The study revealed that formwork from wood/timber, Mortar from Rendering/plastering and Blockwork/ Brickwork are the most wasteful material generated on sites; Design (Frequent design changes and poor design), Poor materials storage system and Theft and vandalism are the most important factors that influence material waste generated during construction. The study recommends that proper site supervision and management techniques, Adequate storage of material, and Staff training and awareness on waste management are the measures of minimizing construction material waste; and saving cost of disposal and transport, increased profit and save construction time loss are the most important benefits of material waste minimization. However, Adewuyi, et al. [9] revealed that the levels of material wastes generated on-site are in excess of estimator's allowance for some materials studied. Therefore, this study surveyed the factors influencing waste generation in building projects across southwestern states of Nigeria [12-19].

\section{METHODS OF THE DATA COLLECTION}

This study was conducted by the use of a structured questionnaire and a field survey to examine the factors influencing the wastage in buildings project across southwestern state in Nigeria. A total of 261 questionnaires were randomly administered to the registered firm of Architects, Builders, Engineers, Quantity Surveyor, Project Manager, across the six (6) state namely Lagos, Ogun, Oyo, Osun, Ondo, and Ekiti State.

The questionnaire administered was divided into three sections. Section A sought to know the general particulars of the respondents, section $B$ was focused on information related to wastage variation of Building materials, while section $\mathrm{C}$ include list of factors that causes Wastage of material on site. The structured questionnaire was analyzed using percentage frequency table and Ranking method.

\section{RESULTS AND DISCUSSION}

Findings on Figure 1, present findings on the professional qualification of respondents. The study revealed that $37.2 \%$ of the respondents were member of Nigerian institute of quantity surveyors, $20.7 \%$ were member of Nigerian society of engineering, $41 \%$ were architect, while the remaining $1.1 \%$ of respondents was either Builders or Project Manager.

Study on Figure 2 present findings on the respective position of respondents. The study confirmed that $30.3 \%$ of the respondents' reside as the post of principal partner/managing director, $29.1 \%$ acting as the project architect, $20.31 \%$ of the respondents' served as the project structural engineer, $3.8 \%$ of the respondents' serving as the project $M \& E$ engineer, $13 \%$ of the respondents' serving as the project quantity surveyor, while only $3.4 \%$ of the respondents' served as the builder. This implies that all the relevant profession was consider during the study.

Findings on Figure 3 present finding on practice years of

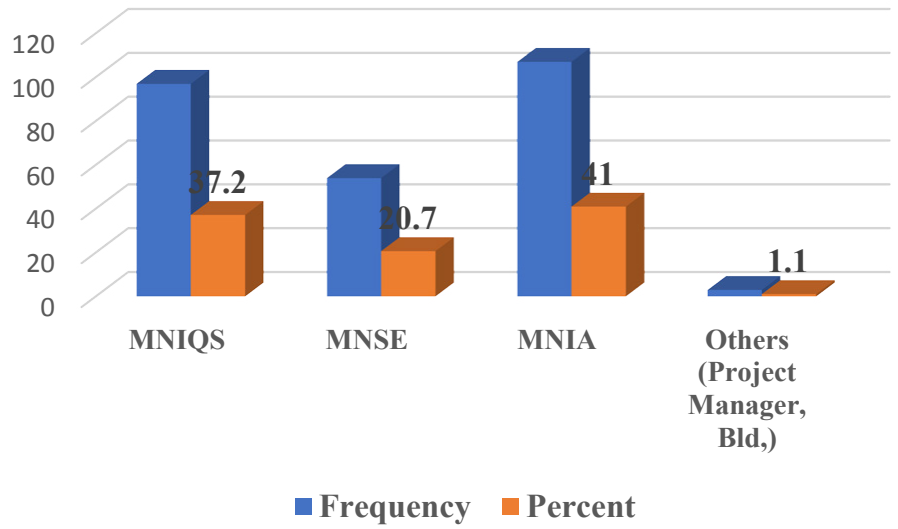

Figure 1: Profession Affiliations of Respondents.

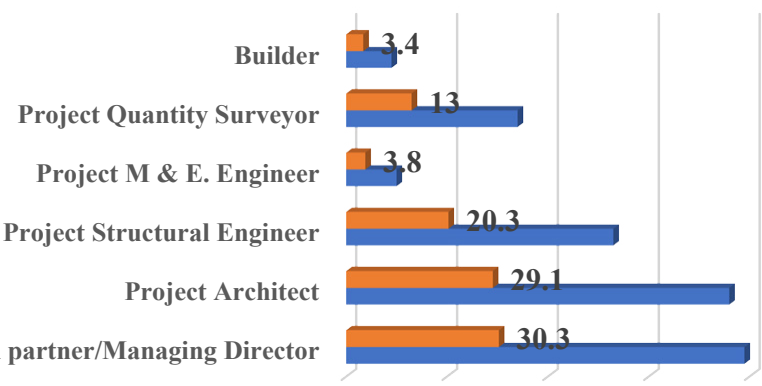

$\begin{array}{lllll}0 & 20 & 40 & 60 & 80\end{array}$

- Percent $\quad$ Frequency

Figure 2: Position-Held by the respective Respondents.

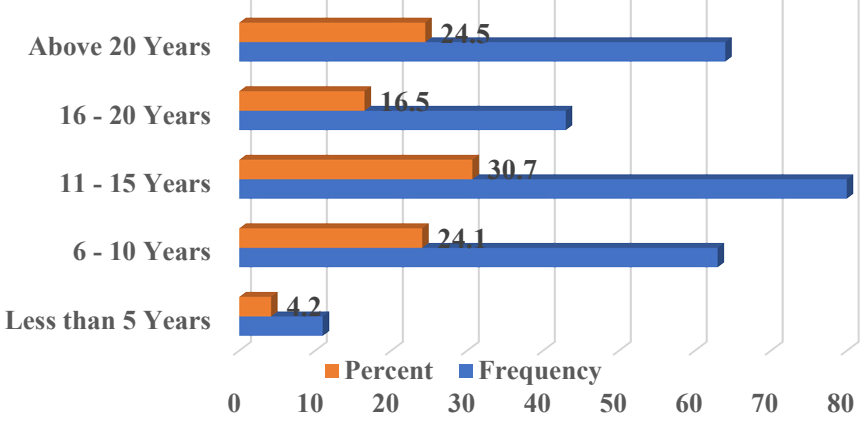

Figure 3: Years in Practices.

respondents in construction sector. The study found that $24.5 \%$ of respondents have had over 20 years of practices experience, $16.5 \%$ of respondents had between 16-20 years practicing experience in the construction sector, $30.7 \%$ had spent between $11-15$ years of practices in the construction sector. $24.1 \%$ of the respondents had between $6-10$ years of practices experience in the construction sector, only $4.2 \%$ of the respondents had less than 5 years practices experience. This implies that majority of respondents had reasonable years of practices experience in building construction sector.

The purpose of the respondent's profile diverse is to obtain more opinions about construction waste factors from different perspectives (Figures 1-3). After, this it is necessary to analyze the score of the factors concerned at which ranked by respondents (Table 1). In response to the ranking of factors influencing waste generation in buildings projects, the study institute that among factors that moderately influences waste generation in building project, lack early involvement of contractor, lack of specific waste minimization directives, unclear project brief, and poor 
Table 1: Rating of Course Factors Influences Waste in Building Project.

\begin{tabular}{|c|c|c|c|c|c|c|}
\hline Factors Influencing Waste in Building Project & Don't Know & None & Little & Moderate & Great & Extreme \\
\hline unclear brief/project defining & 1.1 & 6.9 & 24.1 & 32.6 & 25.3 & 10 \\
\hline undefined project scope & 6.9 & 5.7 & 14.9 & 26.1 & 36 & 10.3 \\
\hline choice of consultant & 5.4 & 5 & 16.9 & 32.6 & 31 & 9.2 \\
\hline choice of procurement method & 2.3 & 5.4 & 18.4 & 26.4 & 43.7 & 3.2 \\
\hline expected very high standards procurement process not client driven & 4.6 & 9.6 & 16.9 & 26.1 & 37.5 & 5.4 \\
\hline no specific waste minimization directives & 2.3 & 7.3 & 12.6 & 37.2 & 31.8 & 8.8 \\
\hline waste management not design directives & 1.9 & 11.1 & 10.7 & 35.2 & 35.6 & 5.4 \\
\hline lack of early collaborative engagement & 5.7 & 6.9 & 13.8 & 29.5 & 37.9 & 5.7 \\
\hline lack of contractor early involvement & 1.9 & 11.5 & 15.3 & 46.7 & 16.1 & 8.4 \\
\hline design of frozen at the end of Architect plan work & 2.3 & 9.6 & 13.4 & 32.6 & 34.9 & 7.3 \\
\hline last minute client requirement & 1.5 & 5.4 & 9.6 & 31.8 & 35.2 & 16.5 \\
\hline cost constraint & 3.1 & 8 & 14.6 & 31 & 31.8 & 11.5 \\
\hline time constraint & 4.2 & 7.3 & 18.8 & 30.7 & 31.4 & 7.7 \\
\hline other design & 11.5 & 16.9 & 32.6 & 23.4 & 12.3 & 3.4 \\
\hline frequent design change & 4.2 & 8.8 & 19.5 & 22.6 & 29.9 & 14.9 \\
\hline design error & 3.1 & 6.5 & 23.8 & 18.8 & 28.7 & 19.2 \\
\hline complicated \& complex design & 2.7 & 4.6 & 12.3 & 32.6 & 34.5 & 13.4 \\
\hline poor design quality & 3.1 & 6.5 & 23.8 & 33 & 22.6 & 11.1 \\
\hline inexperience designer & 2.3 & 17.2 & 15.3 & 18.8 & 26.4 & 19.9 \\
\hline
\end{tabular}

design quality with 46.7\%, 37.2\%, 32.6\%, 33\% respectively were responsible for waste in buildings project.

Among the factors ranked that greatly influences waste generation in buildings project, choice of procurement ranked highest with $43.7 \%, 37.9 \%$ respondents agreed that lack of early collaborative engagement, $37.5 \%$ expected very high standards procurement process not client driven, and $36 \%$ undefined project scope were responsible for waste in buildings project. However, inexperience of the designer, design error, and last minute of client requirement (with 19.9\%, 19.2\%, and 16.5\% respectively) were leading among factors influences waste generation in buildings project among profession in southwest states in Nigeria.

\section{CONCLUSION}

The finding of this study concludes that most important factors that influence waste generation in buildings projects are lack of contractor early involvement, unclear project brief, poor design, choice of procurement method, last minute client requirement, design error, engagement of inexperience design and labour, and undefined project scope.

\section{RECOMMENDATION}

Based on the conclusion of this study, it is recommended that there should be a management directive regarding waste management plan development, engagement of experience and qualify professional, site operatives and craft men should be aware, and trains ways of reducing buildings waste. This will reduce the construction cost, improved output and better storage and handling of materials delivered to site.

\section{REFERENCES}

1. Rahim MH, Kasim N, Mohamed I, Zainal R, Sarpin N, Saikah M. Construction waste generation in Malaysia construction industry: illegal dumping activities. IOP Conf. Series: Materials Science and Engineering. 2017;271:1-9.

2. Seow T. Senario Pengurusan Sisa Pepejal di Malaysia (UTHM: Malaysia: Penerbit Universiti Tun Hussein Onn Malaysia). 2016.

3. Akhund MA, Ali MN, Hussain T, Memon AH, Imad HU. A Comprehensive Review on Waste Generating Attributes: Way Forward for Pakistan's Construction Industry. Engineering science and technology international research journal. 2018;2:1-7.

4. Wahab A, Lawal AF. An evaluation of waste control measures in construction industry in Nigeria. African Journal of Environmental Science and Technology. 2011;5:246-254.

5. Eze EC, Seghosime R, Eyong OP, Loya O. Assessment of materials waste in the construction industry: A view of Construction Operatives, Tradesmen and Artisans in Nigeria. The International Journal of Engineering and Science (IJES). 2017;6:32-47.

6. Adewuyi T, Odesola I. Factors affecting material waste on construction sites in Nigeria. Journal of Engineering and Technology 2015;6:82-99.

7. Dania A, Kehinde J, Bala K. A Study of Construction Material Waste Management Practices by Construction Firms in Nigeria. Proceedings of the 3rd Scottish Conference for Postgraduate Researchers of the Built and Natural Environment, Glasgow. 2007;121-129.

8. Akinkurolere O, Franklin S. Investigation into Waste Management on Construction Sites in South Western Nigeria. American Journal of Applied Sciences. 2005;2:980-984.

9. Adewuyi T, Idoro G, Ikpo I. Empirical Evaluation of Construction Material Waste Generated on Sites in Nigeria. Civil Engineering Dimension. 2014;16:96-103.

10. Aderibigbe YW, Ataguba OC, Sheyin Y. Minimization of wastage of material on construction sites in Nigeria. International Journal of Advanced Academic Research. 2017;3:1-15.

11. Popoola O, Adeleke J, Ayegbokiki S. An Investigation into Material Wastage on Building Construction Sites (Case Study of Selected Building Construction Sites in Osun State). International Journal 
of Science, Engineering \& Environmental Technology (IJONSEET). 2018;3:18-26.

12. Akanni P. An Empirical Survey of the Effect of Materials Wastage on Contractors' Profit Level in Construction Projects. The Professional Builders: Journal of the Nigerian Institute of Building. 2007;35-46.

13. Aleksanin A. Development of construction waste management. E3S Web of Conferences. 2019;97:1-7.

14. Hassan SH, Abdul Aziz H, Adlan MN, Johari I. The causes of waste generated in Malaysian housing construction sites using site observations and interviews. International Journal of Environment and Waste Management. 2015;15:295-308.

15. Khaleel T, Al-Zubaidy A. Major factors contributing to the construction waste generation in building projects of Iraq. MATEC Web of Conferences. 2018;162:1-6.
16. Lee CF, Ismail Abdul Rahman AA, Sasitharan N, Khairul IK. Classification and Quantification of Construction Waste at Housing Project Site. International Journal of Zero Waste Generation. 2013; $1: 1-4$.

17. Luangcharoenrat C, Intrachooto S, Peansupap V, Sutthinarakorn W. Factors Influencing Construction Waste Generation in Building Construction: Thailand's Perspective. 2019;11:1-17.

18. Oladiran OJ. Innovative Waste Management Through the Use of Waste Management Plans on Construction Projects in Nigeria. Journal of Architectural Engineering and Design Management. 2009;5:165-176.

19. Pakhare MS, More A, Bhalerao N. To Indentify the Root Causes For Wastages of Construction Materials. IJARIIE. 2017;3:2137-2139. 